\section{Vale S.A.: Cobalt Streaming}

Vale S.A .: Operação de Streaming de Cobalto
Flavia D'Albergaria Freitas ${ }^{1 \oplus}$ Carlos Heitor Campani ${ }^{1 \oplus}$ Viktor Nigri Moszkowicz ${ }^{\circledR}$ Raphael Moses Roquete ${ }^{1}{ }^{\oplus}$ Flavia Schwartz Maranho ${ }^{\circledR}$

\section{INTRODUCTION}

It was a beautiful sunny morning in Rio de Janeiro in late May 2018. Luciano Siani Pires, Chief Financial Officer (CFO) of Vale, a Brazilian mining company and one of the largest in the world, was preparing for a meeting with his team to decide the future of a large and meaningful project. Known as Project Power, it involved negotiating a streaming transaction, which allows mining companies to sell a portion of the future production of a mine. In this kind of transaction, one company, paying in advance, acquires all or a portion of the production of a mine's by-product.

Vale was the owner of an open-pit mine in the province of Newfoundland \& Labrador in Canada, operating since 2005. The Voisey's Bay was a nickel mine with cobalt and copper by-products. Although the open-pit mine had been almost depleted, the underground mining still had enormous potential. However, to make this possible, a large investment was required. Vale had already committed to the province to invest, and if the company failed to comply, it would have to pay a large fine.

Therefore, the main objective of Project Power was a cobalt streaming transaction to de-risk the returns on the capital employed to develop the Voisey's Bay Mine Expansion (VBME) underground project. The streaming transaction would enable Vale to take advantage of core metals, including nickel and copper, while preserving some exposure to cobalt. Streaming transactions were not new to Vale. The company had already executed over US\$ 3.7 billion in four streaming transactions - however, none with the complexity and importance of VBME.

JEL Code: L72, A2, C44.

\footnotetext{
'Universidade Federal do Rio de Janeiro, Instituto de Pós-Graduação e Pesquisa em Administração (COPPEAD), Rio de Janeiro, RJ, Brazil.

${ }^{2}$ Vale S. A, Finances, Rio de Janeiro, RJ, Brazil.

${ }^{3}$ Centro Universitário Celso Lisboa, Escola de Negócios, Rio de Janeiro, RJ, Brazil.
}

Cite as: Freitas, F. D., Campani, C. H., Moszkowicz, V. N., Roquete, R. M., \& Maranho, F. S. (2020). Vale S.A.: Cobal streaming. Revista de Administração Contemporânea, 24(6), 600-617. htrps://doi.org/10.1590/1982-7849rac2020200019
Editor-in-chief: Wesley Mendes-Da-Silva (Fundação Getulio Vargas, EAESP, Brazil) Associate Editor. Paula C. P. de S. Chiment Reviewers: Henrique Castro Martins (Pontificia Universidade Cat Daniela Abrantes Ferreira (Universidade Federal do Rio de Janeiro, COPPEAD, Brazil) $\mathbb{C}$

Received: January 21, 2020 Last version received: May 21, 2020 Accepted: May 25, 2020

\# of invited reviewers until the decision:

\begin{tabular}{|c|c|c|c|c|c|c|c|c|c|}
\hline & 1 & 2 & 3 & 4 & 5 & 6 & 7 & 8 & 9 \\
\hline $1^{\text {st }}$ round & x & 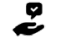 & x & $\stackrel{8}{2}$ & & & & & \\
\hline $2^{\text {nd }}$ round & 2 & 2 & & & & & & & \\
\hline $3^{\text {rd }}$ round & $\stackrel{9}{c}$ & & & & & & & & \\
\hline
\end{tabular}


It was a complex process that started in December 2017, and it was about to finish. More than sixty parties were contacted when Vale and BMO Capital Markets launched the formal stream process. And five months later, only five reached Phase II, and three caught Luciano's attention. Cobalt 27, a Cobalt-related startup, had offered a good price for the metal involved in the streaming transaction. Yet they had no financial capacity to commit the volume Vale wanted: to negotiate around $75 \%$ of the future cobalt production. Wheaton Precious Metals (Wheaton) could commit to the volume that interested Vale with a similar nominal price but with staged payments. There was a third important player to be considered, TradeCo, which tardily offered the highest price but for a slightly lower volume than the whole stream on sale, and it would require more time and extra risk for execution. Luciano looked at that scenario and wondered which path to take at these crossroads. He knew that a higher price was critical to the project's return and to make the expansion of the mine a lucrative deal. But a higher price would be useless if a lower volume was purchased. Keeping the transaction's characteristics within the parameters that allowed it to be classified as equity rather than debt was also an important aspect that needed to be preserved, as this could have an impact on the risk-return profile. He was reflecting on the whole process while waiting to join his team to decide the last steps of the negotiation.

\section{VALE S.A.}

Vale is one of the largest metals and mining companies globally, with a market capitalization of above US\$ 70 billion. Vale S.A. is a global leader in iron ore pellets and nickel. The company headquarters is in Rio de Janeiro, Brazil, and is present in 27 countries over five continents producing manganese, ferroalloys, copper, platinum group metals (PGM), gold, silver, cobalt, metallurgical, and thermal coals. To ensure support for the transportation of the ore produced, from mining to delivery to customers, Vale has railways, ports, distribution centers, and carries out maritime chartering activities.

Vale was founded in 1942 to exploit iron ore in the Itabira region of Minas Gerais. After its foundation, Vale gradually expanded its iron ore production, but still very slowly. It was only from the 1960 s that the company grew more sharply. During those years, its production went from 10 million tons/year in 1966 to 18 million tons/year in 1970 and reached the incredible amount of 56 million tons/year in 1974 when the then stateowned company became the global leader in the export of iron ore. Vale was privatized on May 6, 1997. A consortium headed by the Brazilian CSN (the National Steel Mill Company) - CSN sold its shares later on -, pension funds, and the Brazilian Development Bank (BNDES - Banco Nacional de Desenvolvimento Econômico e Social) acquired Vale's control.

The company operates in four major business segments:

1. Ferrous minerals, with four mining systems in Brazil that produce and distribute iron ore, operate pelletizing plants, as well as operate manganese.

2. Base metals, by producing and processing nickel, copper, cobalt, platinum group metals, and other precious metals.

3. Coal, with metallurgical and thermal coal operations primarily in Mozambique.

4. Logistics infrastructure is a leading logistics service operator in Brazil and other regions with railroads, maritime terminals, distribution centers, and ports.

In 2017, the main segment was ferrous minerals, representing $74 \%$ of the revenue. However, base metals provide an important diversification strategy for Vale. In line with this strategy, on October 24, 2006, Vale announced the acquisition of Canadian company Inco Limited, the largest nickel miner in the world, consolidating its internalization process.

\section{VOISEY'S BAY MINE EXPANSION (VBME)}

Voisey's Bay Mine was discovered in 1993 in the Canadian province of Newfoundland \& Labrador, approximately $1,200 \mathrm{~km}$ north of St. John's, and was acquired by Inco Limited in 1996. Later, in 2005, the open-pit mine and concentrator became operational. It produces over $600 \mathrm{kt}$ of nickel, $400 \mathrm{kt}$ of copper, and $12 \mathrm{kt}$ of cobalt per year, and is one of the most competitive nickel operations globally, with cash costs $^{1}$ in the first quartile of the industry cost curve. One year later, in 2006, Vale acquired Inco Limited and, in doing so, the ownership of Voisey's Bay. The site consists of an open-pit mine, a concentrator, one tailings facility, one diesel power generation facility, an airstrip, an accommodations complex, concentrate storage, fuel storage, and port facilities. 
However, the current mine would cease before 2023 without the development of the underground project. An exploration around the Ovoid Deposit identified two major deposits - Reid Brook and Eastern Deeps - located from $200 \mathrm{~m}$ to $900 \mathrm{~m}$ underground. They have a combined resource content of around 24 million tons of ore at $2.1 \%$ nickel, $0.9 \%$ copper, and $0.14 \%$ cobalt with both deposits still open to depth. A feasibility study was completed in early 2015 to expand Voisey's Bay operations underground to mine both deposits via two decline and ramp systems. The project would allow Vale to extend Voisey's Bay mine life from 2023 to 2034, maintaining nickel output levels, while also yielding significant amounts of copper and cobalt.

The Voisey's Bay Project was governed by the September 30, 2002 Development Agreement, which was amended, between Vale Newfoundland \& Labrador, Vale Canada and the province of Newfoundland \& Labrador. This agreement set out the terms under which Vale could develop the nickel, copper, and cobalt deposits at Voisey's Bay. One of the key elements of the agreement was the construction of an underground mine at Voisey's Bay, including commitments to completion timing of those underground mines. If Vale failed to accomplish the project, the company would be subject to a Can $\$ 427$ million abandonment charge (something close to US\$ 310 million). To avoid abandonment, Vale was required to start mining by December 31, 2022. The balance of the abandonment charge reduces as the construction of the underground mine advances. Vale knew how important it was to accomplish the agreement. The company was already working with the government to ensure that Vale's current underground mine project schedule was consistent with its obligations in the Development Agreement. Vale already had to negotiate the original dates with the province, as Long Harbour took longer to be built.

In addition, as Voisey's Bay is in an area subject to land claims by Aboriginal groups, Vale has also entered into impacts and benefits agreements: Over $50 \%$ of Vale's workforce at Voisey's Bay are people from these Aboriginal groups, most of whom live in adjacent communities. Moreover, Vale encourages Aboriginal students to further their education through site visit promotions, school awards, and scholarships.

Additionally, the province of Newfoundland \& Labrador had set a high standard for safety performance. Stewardship of performance was provided by Aboriginal groups representants, stationed full time at the mine site. There was a single small exceedance at Long Harbour (nickel in effluent), though no environmental effects were observed. Voisey's Bay was one of six mine sites awarded with the Mining Association of Canada's (MAC) Towards Sustainable Mining (TSM) Leadership Award in 2016. It was the recipient of the Community Engagement Excellence Award in 2017 for the Winter Shipping Program.

Voisey's Bay Mine Expansion (VBME) represented significant volumes of nickel, copper, and cobalt, offering attractive returns in current market conditions as low unit costs position VBME well amongst competitors. The underground project was expected to produce an average of 44,000 tons per year of nickel-in-concentrate to be shipped to Vale's processing facility in Long Harbour at full production. In addition to nickel, the Voisey's Bay underground would be an important producer of copper and cobalt (see Exhibit 1), as stated by Eduardo Bartolomeo, Executive Officer for Base Metals at the time and soon to become CEO.

By unlocking the value of the cobalt by-product at Voisey's Bay through this streaming deal, Vale has found a way to resume substantive work on the underground project in Voisey's Bay and support the market's increasing demand for nickel, copper, and cobalt, as well as upholding its commitment to the Government, our Indigenous stakeholders and the people of Newfoundland \& Labrador, Canada.

\section{COBALT}

Cobalt, nickel, and copper are all metals exposed to the electrification of vehicles. Cobalt is a hard, lustrous metal with high energy density, low thermal conductivity, possibility for alloy and ferromagnetism, which results in diverse commercial, industrial, and military applications. Cobalt is primarily used in battery technology, especially in the rapidly expanding electric vehicles (EV) market. In 2007 , only $23 \%$ of the cobalt produced was used in batteries. By 2016, already $50 \%$ of the cobalt was used for this purpose.

The demand for cobalt for battery-related end-use is expected to grow even more as cobalt significantly improves stability and life span of rechargeable batteries. This demand is expected 
to more than double between 2018 and 2025. The price of cobalt recently spiked from the anticipated demand from electric vehicle batteries (see Exhibit 2). This growth can be validated by the latest news about car manufacturers' investments in electric cars. In 2017, for example, Volkswagen approved a $€ 34$ billion (roughly US\$ 40 billion) spending plan to become a global leader in electric cars. But they were not alone. Ford Motor Co announced that it will significantly increase its planned investments in electric vehicles to US $\$ 11$ billion by 2022 and had 40 hybrid and fully electric vehicles in its model lineup. In September 2017, British technology company Dyson confirmed that it had been working on a battery electric vehicle for three years and was investing $£ 2$ bn (US\$ 2.7 billion). Global electric car sales finished March 2019 with 224,000 sales for the month, up 53\% from March 2018, with market share at $2.8 \%$ in March. There was a growing consensus that EV production would grow exponentially. Volkswagen, for example, predicted EVs would go mainstream in 2022. This was possible because EVs were becoming cheaper faster. By 2025, they were expected to be less expensive than petrol cars.

The two main global supply risks for cobalt were related to its geographic concentration and its by-product nature. Two-thirds of world cobalt mining supply comes from just three countries, with the Democratic Republic of Congo being the dominant supplier. The social-political issues associated with cobalt extraction, mainly in Congo, have always been a challenge for the cobalt output ramp-up. Up to $20 \%$ of the cobalt from the Congo comes from artisanal mines, most of it is mined by hand, using basic tools to dig out rocks underground. Unicef estimated that around 40,000 children work in mines across the southern Congo, many of them in cobalt mines. Due to this problem, some companies have already stopped buying cobalt from Congo. However, a new mining code in Congo is likely to lead to higher costs for consumers of battery metal cobalt, as the code will impose higher royalties on cobalt.

Cobalt is a by-product of copper and nickel. Therefore, cobalt production is tied to the economics of those two metals rather than to the cobalt market. The demand for cobalt alone is unlikely to justify starting new copper and nickel mines. The timing of supply growth of copper and nickel versus timing of demand growth for cobalt may result in continued cobalt deficits that could lead to persistently high prices. The market realized that and some companies like Tesla and Apple already tried to secure their own supplies by signing longterm deals with miners.

\section{THE TRANSACTION}

The streaming transaction, identified by Vale as Project Power, was a way to make the mine expansion financially viable and to de-risk the returns on the capital employed to develop the VBME underground project. Streaming transactions were very common with precious metals such as gold and silver, but Vale was proposing the biggest transaction ever with base metals.

\section{Streaming transactions}

Streaming is an agreement where one company acquires all or a portion of the production from a particular mine of its finished by-product paying in advance. The miner delivers metal to the acquirer as it is produced.

The acquirer's advance amount will fund most of the purchase price of the metal that will be delivered over the term of the contract. The acquirer will also pay an ongoing transfer price for the metal as it is received, which will constitute payment for the remainder of the value of the metal delivered. However, the transfer price will be either a fixed amount or a percentage of the spot price, depending on the preferences of both parties.

By streaming a portion of the mine's future production, the mining company may raise capital on relatively attractive terms. The company assumes the responsibility for the reserve and the metal's production, as well as the price risk of its share of the project. At the same time, selling a portion of the future production is more conservative and presents a lower risk than debt financing. Typically, streaming is not classified as debt financing. However, the mining company forgoes the future cash-generating capacity of a portion of its project, regardless of whether the terms are treated as debt or equity. Streaming differs from a debt transaction as it does not entail payments that are fixed or determinable in amount and timing, nor does it entitle the debt holder to a claim on company assets in case of bankruptcy. Thus, the mining company records the initial upfront payment as deferred revenue on the balance sheet. It can amortize the amount into revenue with each delivery. This financing scheme is likely to be a cheaper alternative than raising equity in capital markets if that alternative is actually available. 
Therefore, the transaction offers benefits to both sides. While the mining company gains a source of capital with lower risk compared to bank or credit financing, the streaming company benefits from an opportunity to invest in the mine and capitalize on any upside in metal prices.

The metal streaming companies offer capital at competitive terms in exchange for a stream of metals. The shares of streaming companies usually trade with a price premium in relation to fundamental value as they typically have a lower cost of capital and can share part of the benefit with sellers. The lower cost of capital by streaming companies is mainly explained by portfolios of high-quality assets, unlimited upside potential, diversification in terms of counterparties, mineral provinces and geographies, and limited risk of Capital Expenditure (CAPEX) overruns or operational costs variations as far as operations continue running to produce the metals.

Nevertheless, the transaction includes completion guarantees. It requires the mining company to repay the remaining deposit if it does not complete the project by a certain date. Completion guarantees could render the arrangement debt-like if there is a high likelihood that the construction will not be completed in the required timeframe, and if any required repayment would be material to the company.

To design the transaction, BMO Capital Market (Vale's advisors during the transaction) presented studies about precedent streaming transactions. A total of 36 precious metals precedent streaming transactions on development assets were analyzed to identify common structural characteristics as well as to isolate key value drivers.

Based on this analysis, it was identified three key drivers that needed to be defined for the Power Project: the stream percentage, the transfer price, and the exposure to the geological upside. In general, vast majority of streams provide the purchaser with exposure to future exploration upside. The extent of the exposure provided varies. Most stream agreements cover all mineral rights, concessions, and interests and future production on the property within a defined area without any limitations on the upside within the defined area that the stream covers. On the other hand, only a small number of streams limits the purchaser's exposure to the upside by adopting tiers, which cause either the stream percentage to decrease or the transfer price to increase after a certain amount of metal has been delivered. Some streams include an option for the purchaser to acquire a stream on future discoveries in the area.

Regarding the transfer price, from a seller's perspective, a fixed transfer payment generally eliminates exposure to commodity prices. In contrast, a transfer price as a percentage of spot maintains exposure to commodity prices, both on the upside and the downside. Historically, most streams have fixed transfer prices, ensuring that all commodity price exposure is with the purchaser. However, recent streams have seen this trend change (transactions 2015 onwards), with an even split between streams with fixed transfer prices and streams with a percentage of spot transfer prices. Most percentages of spot transfer prices are in the $20 \%$ to $30 \%$ range.

Regarding the stream percentage, a sale of a $100 \%$ stream of a by-product is a viable option with precedents and would not be unusual. Purchasers would need to be comfortable that Vale is still incentivized to maximize the production of cobalt. In some cases, they may be able to obtain comfort from understanding geology and processing. If the purchaser has concerns about Vale's incentives, the stream could be structured to fix the amount of cobalt to be delivered based on a ratio to nickel production (thereby transferring this risk from the purchaser to Vale). The impact of selling a $100 \%$ stream vs. 75\% stream on Voisey's Bay's cash costs and cash flow margins would need to be considered to ensure that Vale is comfortable with the stream's impact.

\section{The transaction history}

The Voisey's Bay Mine Expansion was approved in July 2015 by Vale's Board of Directors. With the approval, the project kicked off. Consequently, it was necessary to begin its engineering detailing phase. Hence the project team began detailing the schedule. However, in May 2017, Fabio Schvartsman became Vale's CEO and asked to stop all project developments, to do what he called the 90-day review. Vale was undergoing a restructuring period with the end of the commodity cycle. Specifically, in Voisey's Bay, the nickel price was low, so the project return was not satisfactory. As stated by João Zanon, VBME project director:

VBME was Vale's largest capital project outside Brazil, but the price of nickel was very low. The initial estimate was for an investment of 
US\$ 1.9 billion: US\$ 200 million in 2018, US\$ 450 million in 2019, US\$550 million in 2020, US\$ 450 million in 2021 , US\$ 200 million in 2022, and US\$ 50 million in 2023. So, if we looked at the project economics, the return on investment was yielding around $10 \%$, or even less depending on what its long-term nickel price assumption was. While if you looked at the iron ore projects, you would get at least $30 \%$.

Those economics left Vale with a difficult decision. Typically for commodities projects, the economics needs to be high whenever a scenario of expected low prices occurs due to the risk of unpredicted events that could delay the project and thus make it financially unfeasible. Especially for VBME, the project was risky as the mining was in an inhospitable Arctic environment, with fewer possibilities to choose contractors. The economics was close to breaking even. Vale could not run a project "that barely returns the cost of capital in today's prices," as Luciano stated.

However, he knew that in replacement projects, the decision not to go with the investment means that it would be necessary to close the operation and let it die. And this is a hard decision because it is usually irreversible. In Luciano's words:

You have to get rid of your specialized workforce. You generate all the institutional stress that you cannot operate afterward. Even in a future scenario where the price improves, you would need to rehire everyone, rebuild the relationship with the province. So, not investing would be a farewell, almost irreversible. It's a goodbye, not a 'see you soon.'

Therefore, the project was put on hold for an independent review for optimization opportunities and to explore funding alternatives. CAPEX was revised, from an opportunity standpoint, resulting in a reduction from around US\$ 1.9 billion to something close to US $\$ 1.7$ billion. Technical changes were made by altering the power generation plants and modifying the access defined to the mine.

With the revision, the estimated capital expenditures for the expansion were, with the usual predictability risk that such a project encompasses, as follows: US $\$ 150$ million in 2018 , US $\$ 350$ million in 2019 , US $\$ 450$ million in 2020, US\$ 450 million in 2021, US\$200 million in 2022, and US\$ 50 million in 2023. These estimates are deflated, which means that they do not consider inflation effects. The first full year of underground production is expected to be 2020 when current open-pit mining begins to ramp down. During the operating time, from 2020 to 2034, the underground mine is expected to produce 514,000 metric tons (t) of nickel, 216,000 t of copper, and 34,000 t of cobalt (Exhibit 1).

At that moment, the first economic feasibility studies for VBME considered that the Voisey's Bay underground project would provide ore to the site concentrator until 2034, and the Long Harbour processing plant's annual capacity is $50,000 \mathrm{t}$ of finished nickel. The expected deflated prices for the metals were US $\$ 14,000 / \mathrm{t}$ for nickel; US $\$ 30,000 / \mathrm{t}$ for cobalt; and US\$5,000/t for copper. Taking into consideration the revised CAPEX of around US\$ 1.7 billion, the Internal Rate of Return (IRR) would be around $6.5 \%$ in real terms, still too low.

With the independent review completed, the next focus was on exploring funding alternatives before fully implementing the project. Along with some advisors, Vale decided to do the streaming transaction with cobalt. Vale's executive knew that it was a challenging deal, as explained by Matt Cherevaty, New Business Development in Base Metals specialist.

It was a very noble idea to do the streaming of cobalt. It was the first one in the world, especially with that magnitude. Gold and silver were pretty common but doing base metal streaming was novel. But there were challenges as well. As we were giving a physical product and the physical product does change, depending on how well the plants run, we had to put specifications into the agreement on the quality of the cobalt.... So, it brought a lot of complexity to the agreement just because of how cobalt is handled.

It is valid to highlight one important difference between a gold and a cobalt streaming transaction. While there is a mature and liquid market for trading gold, a gold delivery can be made through a paper trade to liquidate the obligation. However, in the case of cobalt, the producer should indeed deliver the physical product. In any case, the technical area had already attested that it was possible to produce quality cobalt at the Long Harbour refinery. Moreover, the cobalt market was increasing due to electric vehicles, and, at the same time, there were supply problems in the Democratic Republic of Congo, in Africa. All of these changes have made the mine expansion project more attractive. 
On the other hand, there was pressure from the agreement with the province. As Vale had already delayed the Long Harbour processing plant's conclusion, a new delay would be difficult to manage. So, during the process, the company made the government aware of the cobalt streaming deal, ensuring the authorities were aligned with the agreement established with the cobalt buyers.

On December 14, 2017, Vale and BMO Capital Markets launched the formal stream process, and parties were given until February 5, 2018, to conduct their Phase I diligence. To make proposals most comparable, BMO and Vale provided an illustrative term sheet. They asked parties to mark-up the term sheet to reflect their proposed transaction. Table 1 shows the main aspects of the term sheet. They also drew an ambitious timeline. If everything went as expected, the negotiation would finish by the end of April 2018. As Felipe Aigner, Global Director of Treasury and Finance, explained:

We wanted to ensure an extensive competition for the deal, including not only established streamers, but also strategic buyers, private equity firms, financial investors, and traders. Although we had a short timeframe to play in a new space of cobalt streaming, we knew that this transaction was going to value an important asset for the company.

At first, more than sixty parties were contacted, out of which almost half signed the Confidential Agreement (CA). There was a high level of engagement from the majority of parties who signed CAs. Multiple parties engaged advisors to support their review. After that, the parties had access to the data room, a file full of information about the project so they could submit a nonbinding proposal.

Table 1. Main aspects of the negotiation.

\begin{tabular}{|c|c|}
\hline Reference mine & The Voisey's Bay mine in Newfoundland \& Labrador, Canada. \\
\hline \multirow[t]{2}{*}{ Stream } & $\begin{array}{l}\text { The Seller is proposing to enter into a streaming transaction regarding cobalt production from the Stream } \\
\text { Area (the "Stream"). }\end{array}$ \\
\hline & $\begin{array}{l}\text { Commencing on January } 1,2021 \text { (the "Effective Date"), under the Stream the Seller will deliver to the } \\
\text { Purchaser cobalt equal to [x\%] (the "Designated Percentage") of the cobalt production from the Stream } \\
\text { Area. Once an aggregate of [54.0] million pounds of cobalt have been delivered to the Purchaser, the } \\
\text { Designated Percentage shall reduce to [y\%] of the cobalt production from the Stream Area. There are no } \\
\text { minimum cobalt delivery requirements. }\end{array}$ \\
\hline Advance amount & $\begin{array}{l}\text { The Purchaser will provide the Seller with an advance amount of US\$ x million payable upon closing of } \\
\text { the transaction (the "Advance Amount"). The Advance Amount will represent a prepayment of a portion } \\
\text { of the purchase price for cobalt's sale to the Purchaser. No interest shall accrue on, or be payable, in } \\
\text { respect of the Advance Amount. The proceeds of the Advance Amount may be used by the Seller in its sole } \\
\text { discretion. Under no circumstances shall the Purchaser be entitled to a return or refund of any uncredited } \\
\text { Advance Amount (if any) remaining at the end of the Term. }\end{array}$ \\
\hline Additional payments & $\begin{array}{l}\text { The Purchaser will pay the Seller [x\%] of the Cobalt Reference Price (as defined below) (the "Additional } \\
\text { Payment") for each pound of cobalt delivered under the Stream. [The Seller is also open to considering } \\
\text { a fixed transfer price per pound of cobalt delivered under the Stream, subject to appropriate inflation } \\
\text { adjustments.] }\end{array}$ \\
\hline
\end{tabular}

Bidders expressed interest in the opportunity of securing a significant volume of cobalt from a relatively risk-free jurisdiction. But many of them explicitly requested to be partnered at a later stage in the process. The underlying motivation cited by the parties to decline to submit proposals alone, but willing to with varied partners were: limited financial capacity; concerns over significant cobalt exposure, especially for traditional precious metal streamers; lack of conviction around the current run in cobalt prices; and desire for a party with streaming transaction experience to lead negotiations. Many parties were highly interested in securing cobalt but less familiar with the stream financing structure.

On February 5, at the end of Phase I, Vale received 10 proposals, 6 conforming proposals and 4 non-conforming proposals. The six conforming proposals were sent by Cobalt 27, a joint bidder from Wheaton and a partner company, TradeCo, and another three companies. Of the 11 companies for the 10 proposals, four were from royalty and streaming companies; two were from financial investors; two were from resource-focused companies; three were from traders. 
The Bidder's maximum commitment, the streaming percentage, and the reference price varied among the companies. Given this difference among the proposals, BMO calculated the value of all of them. Vale considered some other key points when comparing the proposals: financing conditions, the level of financing confirmation provided by each bidder, initial indications of partnership interest, level of security and guarantees requested in proposal, anticipated Phase II diligence requirements, alternative proposals provided if Vale were to make near-term cobalt production available, and precedent conditions listed in the proposal.

After analyzing the proposals, Vale started Project Power's Phase II. During Phase II, the company that was bidding with Wheaton withdrew from the process, but Wheaton kept participating in the negotiations. At this point, there was an even higher level of engagement in due diligence and data room. Multiple parties engaged technical, legal, and financial advisors to support their diligence. Again, data room had an important role in avoiding information asymmetry, as explained by Matt Cherevaty:

The data room migrated as we went through different parts of the due diligence process with the parties, so, we had a data room open up. It moved from containing a few slides to a very detailed data room with all feasible documents that could support the due diligence. The parties were suddenly allowed to ask questions. We were able to answer the kind of questions they were asking. We added some additional information to the data room to all parties to see, so everybody was getting the same information.

During March 2018, the executives of the six companies were invited to visit both Voisey's Bay Mine and Long Harbour. Cobalt prices sustained high levels during negotiations (Exhibit 2). The price momentum plus the site visit and management presentations helped to increase the Phase II bids.

The Phase II bid deadline was on April 16, 2018, and Vale received bids from Cobalt 27, Wheaton, and another two companies. However, one day later, on April 17, TradeCo submitted a bid as well. In evaluating the Phase II bids, Vale and its advisors considered value, terms, and associated risk of each bid. Based on this, Vale shortlisted the final decision to only three companies: Cobalt 27 presented a high price with the advance amount paid upfront; Wheaton committed with the complete volume for sale but with a lower advance amount and staged payments to be paid during the investment phase of the underground expansion; and TradeCo presented an offer with an even lower price for a lower volume than Wheaton, non-conforming terms, and staged payments of the advance amount.

Finally, Vale decided that it was comfortable proceeding with a smaller stream with Cobalt 27 , as it achieved the cost of capital objectives' terms close to Vale's provided term sheet. Cobalt 27 proposal consisted of an upfront payment of US\$ 300 million for a percentage of $32.6 \%$. So, the company provided consistent feedback to Wheaton and TradeCo. Nonetheless, Vale let them know that they were open to syndicating the remaining stream (42.4\%) if they were able to increase the advance payment and adjust their terms. Syndicating would mean reaching an agreement with not only one investor but sharing the deal between more than one. Besides the price, another favorable condition of Cobalt 27 proposal that would need to be matched was the advance amount being paid upfront.

By the end of April, Vale was already advancing a definitive agreement and documentation with Cobalt 27, when Wheaton provided a revised proposal. In this revised proposal, Wheaton increased the advance amount to match Cobalt 27, maintaining the total designated percentage $(75 \%$ stream), but still considering a staged payment.

Later, in May, TradeCo provided a revised proposal. Over a month after receiving initial Phase II feedback, the company proposed an agreement with the highest price but for a lower volume than the $75 \%$ stream required by Vale, and still with a higher risk of not closing. The company had stated it would require additional months for approvals following completion of the definitive agreements. There was an additional risk: cobalt price was high, and Vale would like to close the deal swiftly before the signature of the amendment of the Development Agreement. By the end of Phase II, Viktor Moszkowicz, transaction team leader, prepared a chart comparing the three proposals (Table 2). 
Table 2. Final bids.

\begin{tabular}{|c|c|c|c|}
\hline & Cobalt 27 & Wheaton & TradeCo \\
\hline Financing capability & $\begin{array}{l}\text { LOW-MEDIUM } \\
\text { Reduced financial capacity } \\
\text { after recent transactions an- } \\
\text { nounced. Relies on raising cap- } \\
\text { ital through a bought deal. }\end{array}$ & $\begin{array}{l}\text { HIGH } \\
\text { Strong balance sheet with cash } \\
\text { on hand and an undrawn re- } \\
\text { volver capacity. }\end{array}$ & $\begin{array}{c}\text { HIGH } \\
\text { Very strong balance sheet. }\end{array}$ \\
\hline Streaming proficiency & $\begin{array}{l}\text { MEDIUM } \\
\text { Recently completed its first } \\
\text { streaming transaction. }\end{array}$ & $\begin{array}{c}\text { HIGH } \\
\text { Highly experienced stream- } \\
\text { ing company, including three } \\
\text { transactions with Vale. }\end{array}$ & $\begin{array}{l}\text { LOW } \\
\text { Lack of experience in stream- } \\
\text { ing negotiation. }\end{array}$ \\
\hline Swift execution ability & $\begin{array}{l}\text { HIGH } \\
\text { Highly motivated to complete } \\
\text { the acquisition as it is core to } \\
\text { its strategy. }\end{array}$ & $\begin{array}{l}\text { HIGH } \\
\text { Strong track record of suc- } \\
\text { cessful acquisitions and deep } \\
\text { transaction experience. Has in- } \\
\text { dicated capability to complete } \\
\text { the transaction within weeks. }\end{array}$ & $\begin{array}{l}\text { LOW } \\
\text { Needed a few months to obtain } \\
\text { internal approval. }\end{array}$ \\
\hline Designated percentage & $32.6 \%$. & $75 \%$. & Slightly lower than $75 \%$. \\
\hline Payment & Upfront payment of US\$300M. & $\begin{array}{l}\text { Same price as Cobalt } 27 \text { (to- } \\
\text { taling US } \$ 690 \mathrm{M}), \text { with staged } \\
\text { payment. }\end{array}$ & $\begin{array}{l}\text { Slightly higher price than } \\
\text { Cobalt } 27 \text { and Wheaton, with } \\
\text { staged payment. }\end{array}$ \\
\hline
\end{tabular}

\section{THE PROJECT ATTRACTIVENESS}

To evaluate the investment in VBME, the transaction team created some scenarios. The idea was to understand the impact of some assumptions, more specifically: the cobalt price was very volatile, the different discount rates, and the different conditions of the streaming agreement. The different risk-return relationships, according to the proposals, were also something to be analyzed. These scenarios could help in the final decision.

Some inputs were fixed between the scenarios: volume from the underground mining, cash cost Operational Expenditure (OPEX), and CAPEX. The volume considered was informed by the technical team and considered the ore produced from 2020 until 2034 (Exhibit 1). The team considered a typical production curve to estimate the yearly production. In the first year, the mine was expected to produce only $0.3 \%$ of the total volume. In the following three years, during the ramp up, it was expected to produce $3 \%, 6 \%$, and $7 \%$ of the volume. The stable production period, from 2024 until 2031, was expected to generate $8.5 \%$ of the volume per year. And finally, during the phase-out, it was expected to produce $8 \%, 6.3 \%$, and $1.4 \%$.
The cash cost considered was US $\$ 11,000$ per metric ton (t) of nickel and CAPEX around US\$ 1.7 billion. For CAPEX, the team also considered sustaining investments, common in mining. The sustaining investment would be $2.5 \%$ of the already invested capital in the previous years. Finally, a tax rate of $34 \%$ was considered.

The metals prices were volatile, so the team made some scenarios to understand the different possibilities. At the beginning of the project, the team had considered the cobalt price of US\$ $30,000 /$ metric ton (t). However, in 2018, there was a price increase, making it difficult to predict future prices. Therefore, they calculated the economics with three different prices: US\$ 50,000/t (minimum consensus), US $\$ 70,000 / \mathrm{t}$ (current consensus LT), and US\$ 95,000 (the current flat-spot price). In all scenarios, the nickel price was US\$16,500/t, and the copper price US $\$ 7,000 / \mathrm{t}$, all figures in real terms at the monetary basis of 2018 .

The new prices were responsible for betterexpected conditions in the project's economics. But it was the streaming transaction that actually locked in a real improvement of the IRR. Luciano explained the importance of the streaming: 
The issue about streaming is that as the payout was upfront, it substantially improves the IRR because it comes in the early stage of the project. NPV does not change that much, but as your capital employed is much smaller, the IRR goes up substantially.

Another relevant decision was the discount rate to be used for the project cash flows. There was a consensus that the project encompassed a higher level of risk compared to a typical Vale project. For instance, the severe temperature and the limited availability of contractors meant a higher risk of a run-out. Consequently, the team used Vale's WACC ${ }^{2}$ and a risk premium. Additionally, they used some data provided by BMO that showed that the median discount rate was $9 \%$ for base metals producers (Exhibit 3).

Finally, some further assumptions concern the streaming agreement to understand how much the economics would change regarding different proposals' details. They needed to build scenarios considering upfront and staged payments, and the different values of payments and streaming percentages. With some consensus, the team considered as target numbers the stream of $75 \%$ of cobalt and an upfront payment at Cobalt 27 price.

\section{THE MEETING}

Voisey's Bay Mine Expansion (VBME) was aligned with Vale's rigorous capital allocation process in which projects must be capable of generating returns at current price levels, instead of depending on future price expectations. However, the Power Project helped to turn the expansion into an attractive project through a streaming transaction. Vale was one of the world's largest metals and mining companies and an experienced partner with streaming transactions. All these highlights were coming into Luciano's mind while he was walking to an important meeting with his team. They had to decide which of the three companies would purchase the cobalt. He knew it was a great opportunity for those companies to participate in a rapidly growing demand for electric vehicles. It was also necessary to take into consideration that VBME offered attractive returns, as it was a lowcost unit and an extension project in a brownfield environment. There was an existing infrastructure and workforce at Voisey's Bay, as the partner could take advantage of the valuable Long Harbour processing plant.
The transaction that started in December 2017 was about to conclude - at least that was Luciano's hope. In 10 days, there would be an event in the Newfoundland \& Labrador province of Canada, and Luciano had committed with the CEO to have finished the agreement so that Vale would announce that the company was able to fund the expansion through the streaming transaction.

While getting to the meeting, Luciano was revising his main objective with the streaming de-risk the mine expansion. He wished Vale could receive an initial payment for $75 \%$ of the cobalt production from Voisey's Bay upfront at the time of the agreement. The partner would also provide additional payments of $20 \%$ of cobalt prices as the product is delivered in the future. In this way, the investor would share with Vale the production and geological risks of the Voisey's Bay expansion project. On the other hand, the investor gets access to the exploration upside potential.

A difficult decision was still ahead. There were three proposals to be considered. Cobalt 27 's proposal offered an upfront payment of US\$ 300 million for a $32.6 \%$ stream, which meant proportionally US\$ 690 for the whole volume of $75 \%$ stream of cobalt. After a final negotiation, Wheaton offered the same price as Cobalt 27, considering the total volume that Vale targeted for the deal, but still with a staged payment. Finally, TradeCo proposed a slightly higher price but with staged payments, for a slightly lower volume than the total stream on sale. However, it required a longer time to close the deal because the company still missed internal approvals - that could bring extra risk. For Luciano, that would mean three or four more months, and that was not what he hoped for as he explained:

Waiting would introduce two additional sources of risk. The market could fall again, which could make all bids unfeasible. Additionally, Vale was already behind schedule with some milestones of the agreement with the province. So, signing the streaming agreement would be an important indication that Vale was really considering the investments and the expansion of the mine.

Although some could think that the bigger transaction would always be better, Mike Baril, Vale's Business Development Manager for Base Metals, advocated a different point of view:

The smaller transaction provided the same deriskiness as the big transaction and left more 
upsides. We should do the small transaction because it has the same de-risking impact but with a much lower opportunity cost. If you want a really good big transaction, the best way to get it is to be willing to commit to the small transaction because then you have negotiation leverage with the other party to say 'effectively, this is a de-risking transaction. It is not about size; we need the right price.

To add even more complexity, the team presented a new alternative: a possible syndicate with two (or even three) of the parties. In this case, more than one company would do the streaming separately. While discussing each alternative's pros and cons, Patricia Rodrigues, director of Corporate Finance with full experience in several M\&A transactions, brought important details about executing this agreement:

If we wanted to syndicate Cobalt 27 with another party, we had to decide on our negotiation strategy regarding the final agreements and the construction of the contract. We had two alternatives. We could negotiate with both in parallel or halt negotiation with Cobalt 27, focus on the incoming member, and then re- engage with Cobalt 27. Our lawyer advised the latter. We had doubts. However, we had a lean team to do concurrent negotiations in different geographies.

The date of the event was not the only pressure. The team had a strong belief that the cobalt price had peaked and could start to fall. So, they were getting worried that the deal might fall apart if they did not speed up and close it.

Luciano thought that the syndication was an alternative. If they decided to do it, how could they negotiate? Dealing with one and then presenting the document to Cobalt 27 would be too risky. And what if they took too long negotiating? And what if Cobalt 27 did not accept the terms negotiated and asked for additional time to approve it? Was it the right decision to give up such a great offer from the third bidder, which could even bring competition and catalyze new increases from others? He knew that although there were a lot of uncertainties, he needed to decide by the end of the meeting. Otherwise, everything could fall apart. However, as he was dealing with such a complex and important transaction, he needed to do all the economics to decide which was the best alternative.

\begin{tabular}{|c|c|c|c|c|c|c|c|c|}
\hline \multirow{8}{*}{ 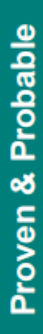 } & & Tonnes & \multicolumn{3}{|c|}{ Grade (\%) } & \multicolumn{3}{|c|}{ Contained Metal (kt) } \\
\hline & & $\mathrm{mt}$ & $\mathrm{Ni}$ & $\mathrm{Cu}$ & Co & $\mathrm{Ni}$ & $\mathrm{Cu}$ & Co \\
\hline & Main Ovoid & 5.8 & $2.67 \%$ & $1.43 \%$ & $0.13 \%$ & 154 & 83 & 8 \\
\hline & Mini Ovoid & 0.2 & $1.37 \%$ & $0.93 \%$ & $0.07 \%$ & 3 & 2 & 0 \\
\hline & SE Extension & 2.8 & $0.71 \%$ & $0.39 \%$ & $0.03 \%$ & 20 & 11 & 1 \\
\hline & Reid Brook & 6.1 & $2.10 \%$ & $0.87 \%$ & $0.14 \%$ & 128 & 53 & 9 \\
\hline & Eastern Deeps & 17.5 & $2.20 \%$ & $0.93 \%$ & $0.14 \%$ & 386 & 163 & 25 \\
\hline & Total & 32.4 & $2.13 \%$ & $0.96 \%$ & $0.13 \%$ & 691 & 312 & 42 \\
\hline
\end{tabular}

\begin{tabular}{|c|c|c|c|c|c|c|c|c|}
\hline \multirow{5}{*}{ 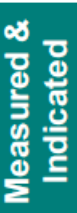 } & & Tonnes & \multicolumn{3}{|c|}{ Grade (\%) } & \multicolumn{3}{|c|}{ Contained Metal (kt) } \\
\hline & & $\mathrm{mt}$ & $\mathrm{Ni}$ & $\mathrm{Cu}$ & Co & $\mathrm{Ni}$ & $\mathrm{Cu}$ & Co \\
\hline & SE Extension & 3.8 & $0.67 \%$ & $0.38 \%$ & $0.03 \%$ & 25 & 14 & 1 \\
\hline & Discovery Hill & 6.5 & $0.99 \%$ & $0.80 \%$ & $0.05 \%$ & 64 & 52 & 3 \\
\hline & Total & 10.3 & $0.87 \%$ & $0.65 \%$ & $0.04 \%$ & 89 & 66 & 4 \\
\hline
\end{tabular}

\begin{tabular}{|c|c|c|c|c|c|c|c|c|}
\hline \multirow{5}{*}{ 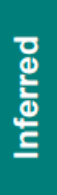 } & & Tonnes & \multicolumn{3}{|c|}{ Grade (\%) } & \multicolumn{3}{|c|}{ Contained Metal (kt) } \\
\hline & & $\mathrm{mt}$ & $\mathrm{Ni}$ & $\mathrm{Cu}$ & Co & $\mathrm{Ni}$ & $\mathrm{Cu}$ & Co \\
\hline & Discovery Hill & 6.8 & $0.9 \%$ & $0.6 \%$ & $0.1 \%$ & 58 & 42 & 3 \\
\hline & Reid Brook & 5.9 & $2.1 \%$ & $0.8 \%$ & $0.1 \%$ & 120 & 49 & 8 \\
\hline & Total & 12.7 & $1.4 \%$ & $0.7 \%$ & $0.1 \%$ & 178 & 91 & 12 \\
\hline
\end{tabular}

Exhibit 1. Voisey's Bay reserves and resources.

Note. The open pit reserves and resources consist of the Main Ovoid, the Mini Ovoid, and the SE Extension. The underground reserves and resources consist of Reid Brook and Eastern Deeps. 


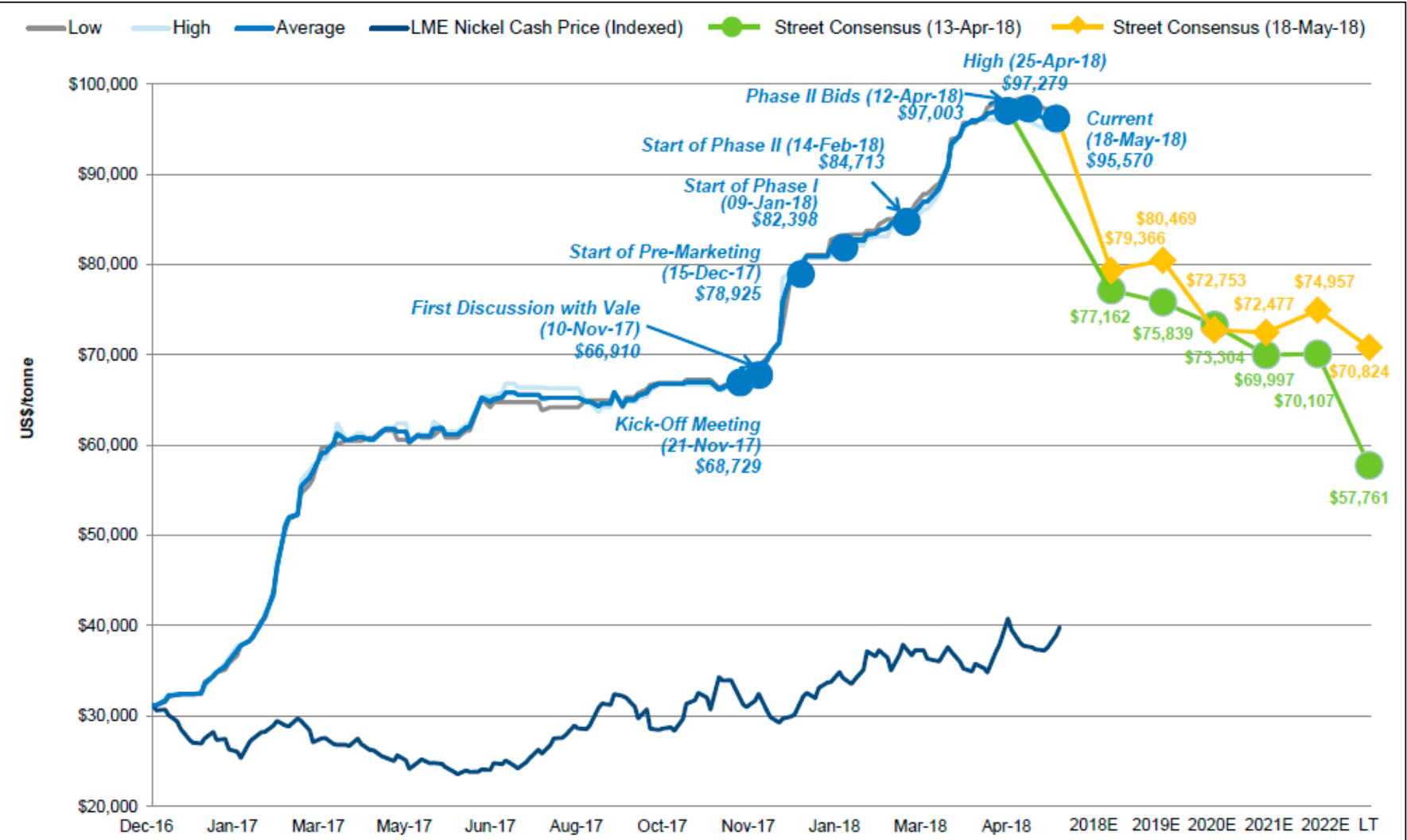

Exhibit 2. Cobalt high-grade free market in Warehouse (US\$/t).

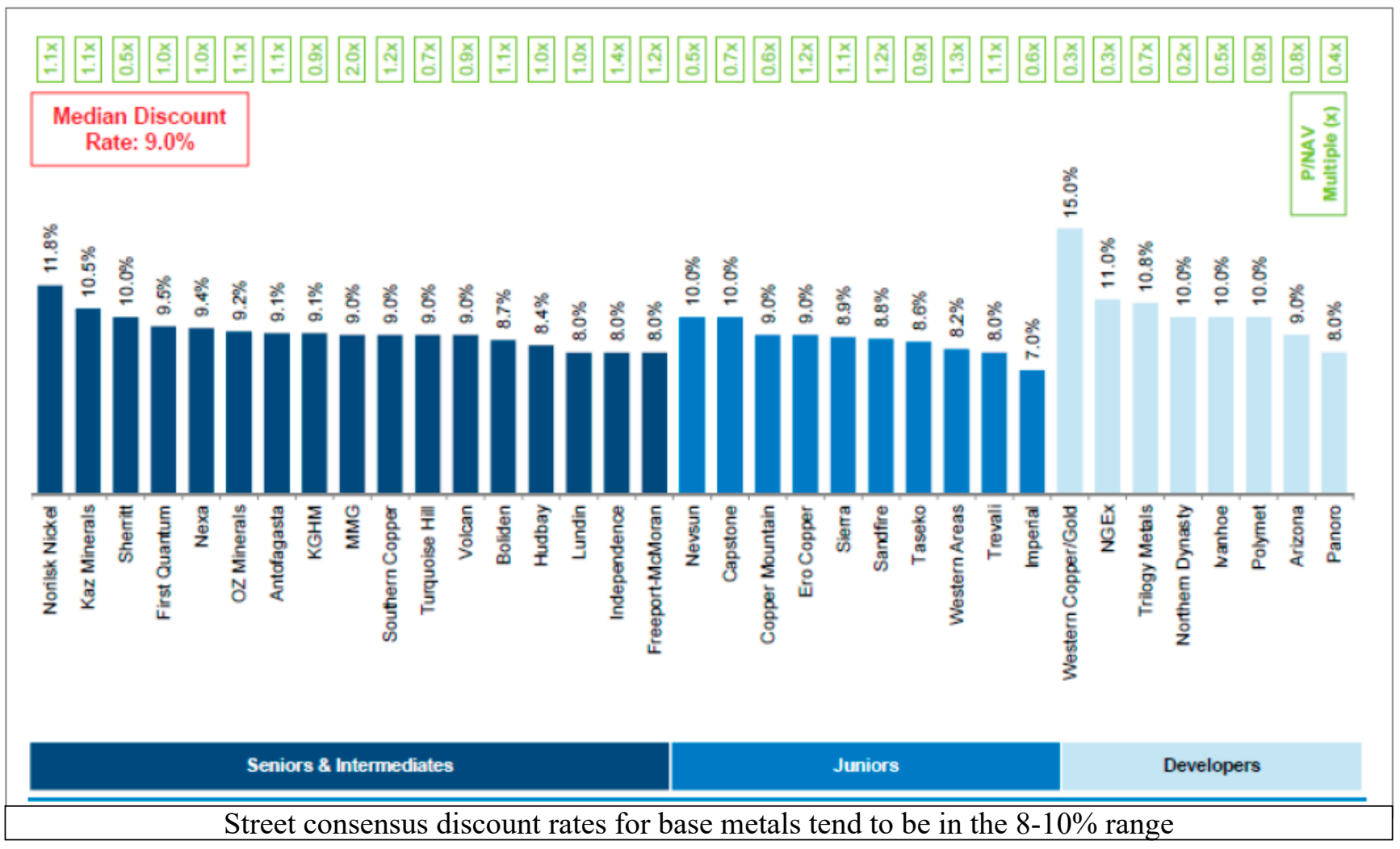

Exhibit 3. Base metals producers / Developers discount rates. 


\section{ABSTRACT}

The case "Vale S.A. - Cobalt Streaming" describes a transaction that has taken place at Vale, a Brazilian mining company, and one of the most important in its segment. The transaction was developed to de-risk an important project for an expansion of a mine in the province of Newfoundland \& Labrador in Canada. By streaming the cobalt production, Vale was able to get a competitive internal rate of return for the project compared to the lower level of risk the project would then offer. The case detailed the negotiation since the beginning until the company faced the challenge of choosing from the final proposals. The case allows the discussion of important aspects regarding project valuation: risk mitigation through the streaming negotiation, several different types of risk influencing the main issue of the case, decisions about the assumptions used, discussion about debt/equity characteristics on the overall project from Vale's perspectives, and the evaluation of a project with non-conventional cash flow, given a substantial upfront revenue due to the streaming contract. So, the case is recommended for the disciplines of Financial Management, Project Valuation, or Risk Analysis in post-graduate courses of Business Administration and Finance.

Keywords: streaming; project valuation; risk/return; teaching case.

\section{Learning objectives}

It is expected that at the end of the case discussion, students can achieve the following learning objectives: (a) understand the relationship between risk and return; (b) understand the impact of the discount rate on project viability analysis; (c) identify the different sources of risk (measurable and non-measurable); (d) evaluate projects with unconventional cash flows. The case is recommended for the disciplines of Financial Management, Project Valuation, or Risk Analysis in post-graduate courses of Business Administration and Finance.

\section{Information sources}

The information used to prepare this case was obtained from primary and secondary sources. Vale's executives and one of the companies' advisors were interviewed. The case is presented from the point of view of Luciano Siani Pires, Vale's CFO at the time the decision was made, and at the time this case was written. As a secondary source, several internal documents were analyzed as well as many journalistic reports about the deal.

\section{RESUMO}

O caso "Vale S.A. - Cobalt Streaming" descreve uma transação realizada na Vale, uma empresa de mineração brasileira e uma das mais importantes em seu segmento. A transação foi desenvolvida para reduzir o risco de um importante projeto para a expansão de uma mina na província de Newfoundland e Labrador, no Canadá. Ao fazer o streaming da produção de cobalto, a Vale seria capaz de atingir uma taxa interna de retorno competitiva para o projeto, tendo em vista o menor nível de risco que o projeto então ofereceria. O caso detalhou a negociação desde o início até a empresa enfrentar o desafio de escolher entre as propostas finais. $\mathrm{O}$ caso permite discutir aspectos importantes relacionados à avaliação de projetos: mitigação de riscos por meio da negociação de streaming; vários tipos diferentes de risco que influenciam a questão principal do caso; decisões sobre as premissas utilizadas; discussão sobre características de dívida/patrimônio no projeto como um todo, sob as perspectivas da Vale; e a avaliação de um projeto com fluxo de caixa não convencional, considerando uma receita inicial substancial devido ao contrato de streaming. Assim, o caso é recomendado para os cursos de Gestão Financeira, Avaliação de Projetos ou Gestão de Risco em cursos de pósgraduação em Administração e Finanças.

Palavras-chave: streaming; avaliação de investimento; risco/ retorno; caso para ensino.

\section{Discussion questions}

The following set of questions could be used to stimulate the analysis of the case:

1. What was the variation in the Project Power economics for the different scenarios?

2. How did the streaming transaction increase the project returns and reduce the risk for Vale, and why did it make sense for its partners?

3. Which proposal was the best alternative for Vale?

\section{Teaching plan}

The case was developed assuming the students' previous individual preparation. The professor should recommend the students to calculate the economics of their analysis. In addition, it is recommended to give a 30-45-minute period for students to discuss the case in small groups prior to the plenary discussion. The total time required for the plenary session may vary 
between 50 and 75 minutes. The opening of the plenary discussion requires 10 to 15 minutes class plan chart column 1 (Figure 1). The analysis of the questions in the case should consume $35 / 50$ minutes - class plan chart columns 2 to
5. The closing of the plenary discussion takes the

remaining 5/10 minutes.

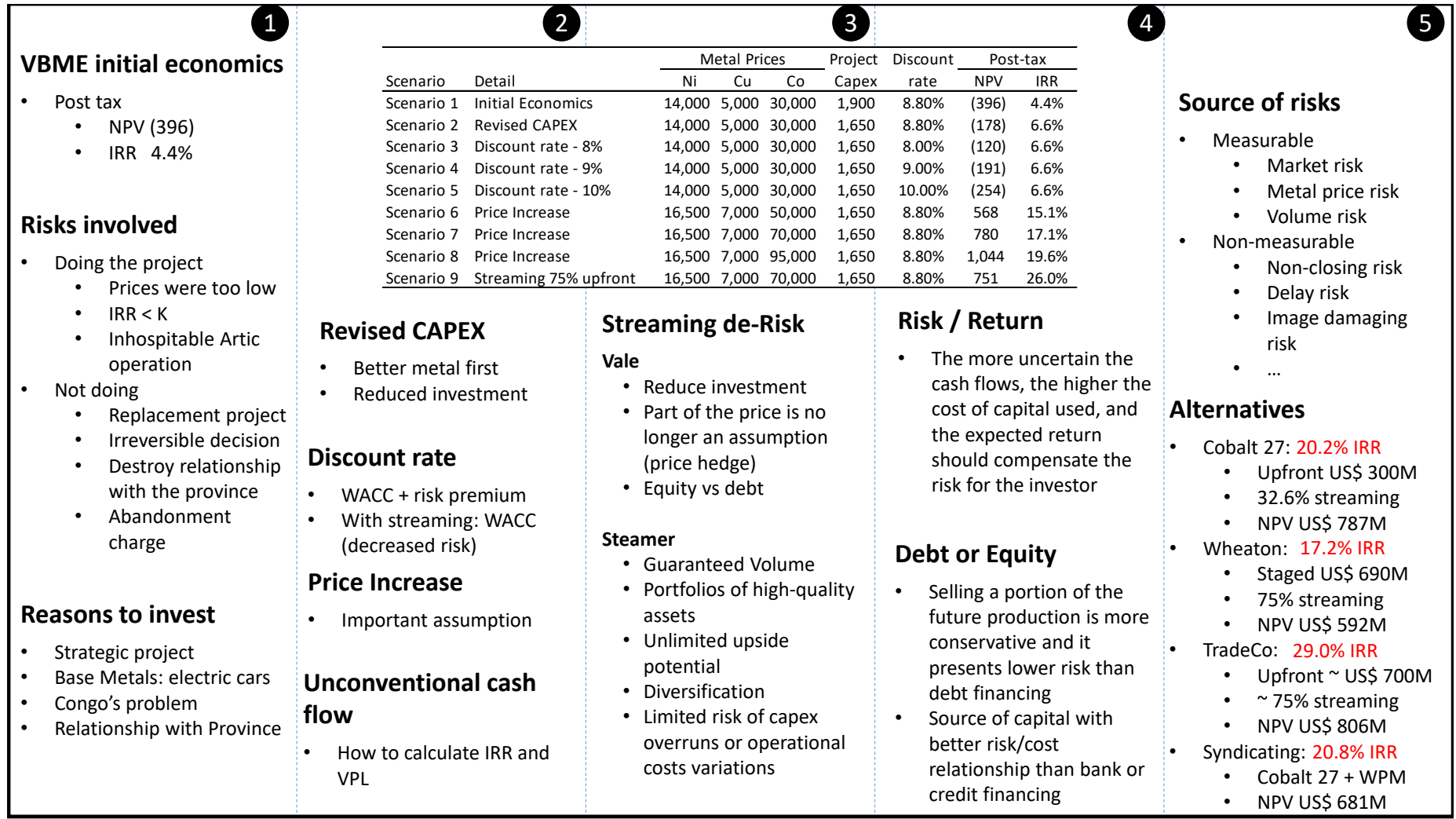

Figure 1. Class plan chart.

\section{Opening of the plenary case discussion}

The professor could start the plenary discussion by asking students to focus on the aspects of the evaluation of the mine expansion project considering the 2015 data. Students are expected to list the assumptions used to calculate the project's initial internal rate of return and assess the risks involved in doing and not doing the project. From the data presented in this case, it is possible to evaluate the attractiveness of the project when it was approved in July 2015 by Vale's Board of Directors.

All assumptions were presented in the case. The commodities prices are on The Transaction History section. The total volume of underground mining was 514,000 metric tons (t) of nickel, 216,000 t of copper, and 34,000 t of cobalt (Exhibit 5). The expected typical production curve is presented on The Transaction Attractiveness section. The operating expenditures considered were based on the cash cost of $11,000 / t$ of nickel (The Transaction Attractiveness section). The initial CAPEX was US\$ 1.9 billion, staged as presented on The Transaction History section. All figures in real terms at the moment of analysis. With all these assumptions and considering a discount rate of $8.8 \%$ per year, the NPV was negative US\$ 396 million. The internal rate of return was $4.4 \%$ for the post-tax cash flow, considering taxes as 34\%. An Excel file is attached to help the professor. This file should not be shared with students, who should build their own.

After calculating the initial economics of the VBME, the professor should assess the risks involved in doing and not doing the project. Although the economics were not good, with a lower IRR than the 
expected return rate, not investing in the mining would mean destroying the relationship with the province and the payment of the abandonment charge. Furthermore, the decision not to go on with the investment means that it would be necessary to close the operation, which would be an irreversible decision.

\section{Discussion questions analysis with literature support}

Q1 - What was the variation in the Project Power economics for the different scenarios?

The purpose of this first question is to enable students to calculate the economics of each scenario to realize how sensitive the results are in relation to each assumption. Whenever we work with a cash flow forecast, we should try to figure out everything that can happen (Brealey, Myers, \& Allen, 2011). It is important for the company to perform sensitivity analyses. Sensitivity analysis allows determining how important output variables are affected based on variations in a given input variable. Scenario analysis can also be used to determine the overall effect of different assumptions on output variables (each scenario is a set of consistent values for the complete set of input variables). It is important that the company's departments identify the main variables that can affect results and provide pessimistic and optimistic estimates of these variables. Some variables that are usually very relevant when evaluating economic projects are costs, prices, and demand (or production). Usually, managers use scenario analysis to produce possible and consistent combinations of variables (Brealey, Myers, \& Allen, 2011).

Using the Excel file as a starting point, the professor could change the assumptions and calculate the NPV and IRR for the different scenarios (Class Plan Chart), through a set of transition questions (TQ).

TQ 1: What was the impact of the CAPEX review on the project's economics?

In Scenario 2, the CAPEX used was US\$ 1,650 million (staged as indicated on The Transaction History section) as a revised CAPEX after Vale hired an independent review for optimization opportunities and to explore funding alternatives. Even with the revised CAPEX, the project still had a negative NPV. Additionally, there was another issue to be discussed: the nature of the operation has a higher risk than a regular project for Vale. So, considering this higher risk, it should be incorporated in the project's economics. The professor should bring this into the discussion:
TQ2: What is the impact of the discount rate on the project's economics?

Another important assumption was the discount rate. In all other scenarios, the discount rate used was $8.8 \%$, based on the public reference for Vale's WACC (informed on The Transaction History section). As the project had a higher risk than a typical project, this risk should be considered in the economics. So, three more scenarios could be considered, regarding the discount rates informed by BMO (Exhibit 3). As BMO informed that the discount rate for base metals range from $8 \%$ to $10 \%$, one scenario was calculated for $8 \%$, another for $9 \%$, and another for $10 \%$. Notice that only the last two scenarios are consistent with the idea that the project had a higher risk than Vale's typical projects. At this point, the professor could start a discussion on the importance of the discount rate. The economic viability of a project is measured by the NPV, and this criterion depends crucially on the discount rate used, which represents the cost of capital of the project. In addition, this rate should reflect the risk of the cash flows (Brealey, Myers, \& Allen, 2011).

After reflecting on the risk through the discount rate, the professor could link to another discussion about the unpredictability of market assumptions. An overly sensitive assumption in this case is the metals' prices. The professor should invite the students to evaluate the impact of different prices in the economics by following the transition question:

TQ3: What was the impact of the price increase on the project's economics?

In the beginning, the prices considered for the base metals were more conservative. However, as the negotiation went on, the prices increased, especially cobalt price. Scenarios 6, 7, and 8 (Table at Class Plan Chart) reflect the different price assumptions for the base metals (The Transaction History section). These scenarios highlight how important the price increase was to make the project attractive. Finally, the professor could address the impact of the streaming transaction with TQ4.

TQ4: What was the impact of the streaming transaction on the project's economics?

Scenario 9 considered an upfront payment of US\$ 690 million for a stream of $75 \%$ and future additional payments of $20 \%$ of the cobalt price for each pound of cobalt delivered (The Transaction History section). Comparing this scenario with Scenario 7, it is possible to notice that the streaming transaction increased the IRR and the NPV. 
The professor should highlight that Scenario 9 does not allow Excel to calculate the internal rate of return for the project. This is because there is unconventional cash flow, starting positive, turning negative, and then positive again. In this case, some would use the NPV criterion. However, this criterion also fails as is explained by Campani (2014). For instance, it is possible to note that from a discount rate of $40 \%$, the NPV begins to rise, making no sense according to the risk-return theory in finance. At this point, the professor could approach how to evaluate projects with unconventional cash flows. Campani (2014) proposed a method to calculate the correct rate of return of any project, including a non-conventional project, and to provide a reliable NPV measure. The author assumes that the initial positive cash flow can be invested at Vale's opportunity cost, matching future negative cash flows until we get a conventional project (a single change from positive to negative). Campani (2014) explains that under certain conditions, this is theoretically correct. These conditions were considered attended by the project analyzed here. In our case, we take the first positive flow forward by the risk-free rate until the flow becomes negative. We considered a riskfree rate of $2 \%$, consistent with the risk-free rate at that time (US\$).

Q2 - How did the streaming transaction increase the project returns and reduce the project risk for Vale, and why did it make sense for its partners?

The purpose of this question is to enable students to assess the concepts of the risk and return relationship in valuation. From Vale's point of view, (a) the transaction reduces Vale's investment in the project, increasing its rate of return; (b) part of the price is no longer an assumption and becomes a pre-fixed value, or in other words, it became a price hedge as it decreases the price volatility; (c) the amount invested earlier by a third party could be considered equity, not debt, which decreases the project risk (and cost of capital). Streaming companies present lower capital costs, which is mainly explained by portfolios of highquality assets; unlimited upside potential; efficient diversification in terms of counterparties, mineral provinces, and geographies; and limited risk of CAPEX overruns or operational costs variations - as far as operations continue running to produce the metals. On the other hand, these companies do not have the operational knowledge that a mining company such as Vale has. Consequently, the deal might be efficient and provide benefits to both sides.

When a company evaluates the viability of a project, it should always consider the uncertainty of cash flows. The company should identify what can contribute to a project succeeding or failing, and then decide if it is worth mitigating uncertainty and continuing with the project (Brealey, Myers, \& Allen, 2011). According to De Oliveira, Lemme, and Leal (2011), the more uncertain the cash flows are, the higher the cost of capital. In other words, the expected return should compensate for the risk (uncertainty) for the investor.

Another important element of the streaming transaction is that it has characteristics of an equity transaction. Selling a portion of the future production is more conservative and presents a lower risk than debt financing. The mining company gains a source of capital with a lower cost of capital compared to a bank or to credit financing. This financing is also likely to be a cheaper alternative to the mining company than raising equity in capital markets if that alternative is available. There is another point that should be discussed in order to explain why cobalt-streaming transactions were challenging. Specifically, base metals streaming is different from gold streaming. Gold is a more mature market. The streaming company pays upfront and does not need to receive the specific precious metal: It gets a gold receipt. This is possible because refined gold is a pure commodity widely traded in the market. However, in the cobalt case, Vale needed to deliver the metal to the streaming company with a certain specification, which raised additional risk for both parts.

Q3 - Which proposal was the best alternative for Vale?

There were three proposals from three partners to be considered: Cobalt 27, Wheaton, and TradeCo. However, there was also the alternative of syndicating two or more companies. Each of these alternatives will be addressed by a transition question.

TQ1: How attractive was the Cobalt 27 proposal?

Cobalt 27 offered an upfront payment of US\$ 300 million for a $32.6 \%$ stream. Considering this, the NPV was US\$ 787 million, with an IRR of $20.2 \%$.

\section{TQ2: How attractive was the Wheaton proposal?}

Wheaton offered the same price as Cobalt 27, considering the total volume that Vale targeted for the deal, but still with a staged payment. This means that the amount offered was US\$ 690 million (300 / 32.6\% * $75 \%)$. As the case does not mention how this payment could be staged, it is assumed a constant payment over 10 years. Considering this, the NPV was US\$ 592 million, with an IRR of $17.2 \%$. Therefore, although the 
Wheaton proposal considered the Vale's total target amount, the IRR was lower as the payment was staged.

\section{TQ3: How attractive was the TradeCo proposal?}

TradeCo proposed a slightly higher price paid up front. However, it was not for the total stream on sale, and it required a longer time to close the deal because the company still lacked internal approvals. As the case does not give the exact amount offered, it is considered US\$ 700 million (slightly higher price than Wheaton) for $75 \%$ (although we do know the percentage was a bit lower). Considering this scenario, the NPV was US\$ 806 million, with an IRR of $29.0 \%$. If on the one hand, this proposal offered the highest NPV and IRR, the risk of not closing would be too high, and not closing would mean that the project would return to Scenario 2 (negative NPV!).

TQ4: How attractive was syndicating more than one company proposal?

Although the IRR with streaming only with Cobalt 27 would appear to be better, it guarantees the price of only $32.6 \%$ of the cobalt production; its NPV was not the highest, and this economics could be worse if the price dropped afterward. So, it would be important for Vale to pursue its goal of streaming $75 \%$ of the mining volume. This could be reached syndicating more than one proposal. The syndicating scenario considered the upfront payment of US\$ 300 million from Cobalt 27 and US\$ 390 million from Wheaton paid in 10 installments. In this scenario, the NPV would be US\$ 681 million, with an IRR of $20.8 \%$. If Vale could negotiate upfront payment with Wheaton, the NPV and IRR would both be even greater: US\$ 796 million and 28.4\% (Scenario 9 - Class Plan Chart), which indicates a good option to be negotiated.

At this point, it is important to emphasize the relevance of the Cobalt 27 offer during the negotiation process to highlight the importance of considering the syndicating instead of closing only with Wheaton. Notwithstanding, syndicating would mean a delay risk for the project as Vale would need to negotiate the terms with two companies instead of only one.

Analyzing only the economic aspects of all scenarios would drive the decision to close (or to syndicate) with TradeCo. However, as previously stated, there was a non-negligible extra risk source (and very difficult to price!) since it would take longer to sign the contract (and also there was uncertainty if the deal would be approved internally by TradeCo). Moreover, Cobalt 27 and Wheaton had also been fair players in the whole negotiation process such that not including one of these companies in the syndicate would, somehow, risk Vale's reputation in a future streaming negotiation.

\section{Closing discussion}

At the end of the discussion, the professor could present how Vale closed the deal. The deal has been widely reported (a Google search can find several reports on the final deal). For example: http://www.vale.com/EN/investors/informationmarket/Press-Releases/Pages/Vale-on-the-closingof-the-cobalt-streaming-transactions.aspx. The professor can also show some extracts from equity research reports from banks that can be found in the internet. As it can be seen from the news and reports presented above, Vale negotiated with Wheaton and got the best scenario: full upfront payment of US\$ 690 million (US\$ 300 million from Cobalt 27 and US\$ 390 from Wheaton) for $75 \%$ of the streaming $(32.6 \%$ for Cobalt 27 and $42.4 \%$ for Wheaton).

To finish the discussion, the professor could ask final questions: "What will happen if Voisey's Bay ends up having a higher level of cobalt? What will happen if cobalt prices from 2021 onwards are higher than it has been expected? What will happen if more reserves are found and/or new investments are required in Voisey's Bay? Would the streaming transaction still be a good strategy?" With these questions, the professor leaves the students with the fact that no decision in finance is risk-free. Although all the risks were considered in the project, there are always scenarios that can make the decision poor ex-post (considered very good exante). Nonetheless, the important analysis is the exante, but the decision-maker must be aware of the expost scenario analyses, weighing them well (ex-ante!). In other words, the decision-maker must evaluate all uncertainties and all scenarios involved, making clear which strategy delivers the best set of scenarios in the future.

\section{ENDNOTES}

1. Cash costs, in mining, are the costs of production, at the site level, per unit of output. Cash costs include operational cash costs such as transport, refining and administration costs, and royalties. Cash costs exclude non-cash costs such as depreciation and amortization, as well as costs not at the site level (such as head office costs).

2. Consider Vale's WACC equal to $8.8 \%$ in real terms and in US\$ (Source: Economatica data services in the period considered above). WACC is an acronym to Weighted Average Cost of Capital. 


\section{REFERENCES}

Brealey, R. A., Myers, S. C., \& Allen, F. (2011). Principles of corporate finance (10th ed.). New York: McGraw-Hill Irwin.

Campani, C. H. (2014). On The rate of return and valuation of non-conventional projects. Business and Management Review, 3(12), 1-6. Retrieved from: https://papers. ssrn.com/sol3/papers.cfm?abstract_id=2676033

\section{Authorship}

\section{Flavia D'Albergaria Freitas*}

Rua Pascoal Lemme, no 355, Ilha do Fundão, 21941-901, Rio de Janeiro, RJ, Brazil.

E-mail address: flaviadaf@gmail.com

๑ https://orcid.org/0000-0003-4870-2864

\section{Carlos Heitor Campani}

Rua Pascoal Lemme, $n^{\circ}$ 355, Ilha do Fundão, 21941-901, Rio de Janeiro, RJ, Brazil.

E-mail address: carlos.heitor@coppead.ufrj.br

๑ https://orcid.org/0000-0003-1896-7837

\section{Viktor Nigri Moszkowicz}

Praia de Botafogo, nº 186, Botafogo, 22250-145, Rio de Janeiro, RJ, Brazil.

E-mail address: viktor.moszkowicz@vale.com

• https://orcid.org/0000-0003-4438-3771

\section{Raphael Moses Roquete}

Rua Pascoal Lemme, nº 355, Ilha do Fundão, 21941-901, Rio de Janeiro, RJ, Brazil.

E-mail address: raphael.moses@coppead.ufrj.br

๑ https://orcid.org/0000-0001-5554-0379

\section{Flavia Schwartz Maranho}

Av. Maracanã, n 526, Tijuca, 2055-142, Rio de Janeiro, RJ, Brazil.

E-mail address: flavia.smaranho@gmail.com

๑ https://orcid.org/0000-0002-6832-7419

* Corresponding Author

\section{Funding}

The authors have received financial support from Vale S.A. to write this case study
Oliveira, F. L. de, Lemme, C. F., \& Leal, R. P. (2011). Cost of equity capital and additionality of brazilian renewable energy projects under the clean development mechanism. Latin American Business Review, 12(4). https://doi.or $\mathrm{g} / 10.1080 / 10978526.2011 .633311$

\section{Authors' Contributions}

$1^{\text {st }}$ author: supervision (equal); conceptualization (lead); writing - original draft (equal); project administration (equal).

$2^{\text {nd }}$ author: supervision (equal); conceptualization (lead); writing - original draft (equal); project administration (equal).

$3^{\text {rd }}$ author: conceptualization (supporting); writing original draft (equal); resources (lead); visualization (lead).

$4^{\text {th }}$ author: writing - original draft (supporting); writing review and editing (equal); validation (equal); visualization (supporting).

$5^{\text {th }}$ author: writing - original draft (supporting); writing review and editing (equal); validation (equal); visualization (supporting).

\section{Conflict of Interest}

The authors have stated that there is no conflict of interest. Although one of the authors works at Vale S.A., the authors were completely independent to write the case as from their standpoint, such that there was no conflict of interest at all.

\section{Copyrights}

RAC owns the copyright to this content.

\section{Plagiarism Check}

The RAC maintains the practice of submitting all documents approved for publication to the plagiarism check, using specific tools, e.g.: iThenticate.

\section{Peer Review Method}

This content was evaluated using the double-blind peer review process. The disclosure of the reviewers' information on the first page is made only after concluding the evaluation process, and with the voluntary consent of the respective reviewers. 